Author version: Review essay on Stephen Prothero's God Is Not One: The Eight Rival Religions that Rule the World and Why Their Differences Matter.

Originally published as Schaefer, Donovan O. “On Dictionaryism: The Good News and Maledictions of Religious Literacy.” Bulletin for the Study of Religion vol 40, no 11 (Apr 2011): 3-8.

Full online version available here: $\underline{\text { http://onlinedigeditions.com/publication/?i=92490\&p=5 }}$

\title{
On Dictionaryism: The Good News and Maledictions of Religious Literacy
}

Within just a few pages of his new book God is Not One: The Eight Rival Religions that Run the World — and Why Their Differences Matter (2010), Stephen Prothero says something that should make every scholar of religion shiver: that he, the author of Religious Literacy (2007), has created "a single book" for those who wish to become "religiously literate" in all of the "great religions" of the world. An ambitious undertaking, indeed, and one that immediately left me skeptical.

But my skepticism was unfounded, and Prothero is no fool. He knows perfectly well that an introduction to a global phenomenon spanning literally all of history cannot be accomplished in the space he has been granted by his publisher. He knows he can't get every religion in the world into a single tent, and he is up front about this in the introduction to his book, and inasmuch as this book is a sort of introduction to the religions of the world, a textbook, it is remarkably responsible.

Not only responsible, but tremendously successful. It amasses huge amounts of detail without overwhelming the reader, and speaks to a lay audience while honoring the complexity and dynamism that scholars of religion insist on with respect to our field. Religions are represented in their variety, their internal heterogeneity, their historical moderations and modifications. Through eight traditionsIslam, Christianity, Confucianism, Hinduism, Buddhism, Yoruba religion, Judaism, and Taoism, with an interesting coda on Atheism-Prothero is our guide with crystal-clear prose, compelling pace, and vaults of detail, stories, and information.

There's even a cutting-edge sheen to the layout of the textbook. Prothero includes an entire chapter on Yoruba religion, not only knocking out the (still?) standard-issue category of "primal" or "indigenous" religions, but making an interesting case for including Yoruba religion as a standalone category of its own in survey work - based on numbers (100 million, by his count) and global reach. I think he's right about this. There's also an interesting chapter on Atheism as religion/not-religion, in which Prothero offers a critical approach to the New Atheist movement without lapsing into the naïve "atheists are evil" rhetoric of some in the religionist camp—conscientiously making space for a "friendly atheism" as an important conversation partner in the religious symposium.

In short, Prothero has written an engaging, detailed, and highly informative primer on the "great" traditions of the world. But there's a major problem with this book, one that would make me think twice before releasing it to unsuspecting undergrads or recommending it to a friend in another field.

The problem, as I see it, is the title. Not that it is misapplied. Prothero makes very clear in the introduction and conclusion to this book that he is opposed to the interpretation of the religions of the world as "many paths up the same mountain," as Huston Smith famously suggested. But the title is designed to be provocative, a body-check to the popular religious discourse floating around these days 
in New Age and New Atheist circles (and every bend in between) that proposes the essential unity of all religions. It is a Bold Statement, the kind of idea that can be easily summarized in a marketing blurb or an Amazon.com review.

This provocative title extends into his provocative, highly polemical Introduction, in which he elaborates on the meaning of the title and why he feels we need to attend to religions as different, rather than the same. For Prothero, the differences between religions matter. What he calls "Godthink," the lumping of all traditions into one shape, "is a lovely sentiment but it is dangerous, disrespectful, and untrue." (2) More specifically, this form of "wishful thinking... has made the world more dangerous by blinding us to the clashes of religions that threaten us worldwide.” (3) If Huston Smith's Perennialism and other forms of Godthink were, as some scholars have suggested, Cold War ideologies designed to shore up an international coalition against encroaching atheism and secularism, Prothero is attempting to articulate a post-9/11 ideology that makes sense out of religious conflict by attending to religious differences. The gorgeous detail and sophistication of the inner chapters of this book, then, is marshaled in service of this objective.

Prothero is absolutely right. All religions are not the same. God is not "one." It is indeed "disrespectful" to overlook these meaningful differentiations. And yet, to my own astonishment, I found myself resisting Prothero's thesis in his Introduction-even though, at least on the surface, I have made the same points he makes many times over.

I puzzled over this as I worked through this text. The Introduction and Conclusion, in particular, set me on edge, and my resistance crystallized and gave itself a name only in the last few pages, when Prothero writes:

people act every day on the basis of religious beliefs and behaviors that outsiders see as foolish or dangerous or worse. Allah tells them to blow themselves up or to give to the poor, so they do. Jesus tells them to bomb an abortion clinic or to build a Habitat for Humanity house, so they do. Because God said so, Jews, Christians, and Muslims believe that this land is their land, so they fight for it in the name of G-d or Jesus or Allah. Call this good news or bad news, but by any name it is the way things are. (337)

I realized what it was that frustrated me about this book, what had been nagging at me since the very first page-when Prothero likened different religious traditions to political systems like "monarchy" and "democracy” or "capitalism" and "socialism"—as if complex political subjectivities could be defined so easily, as if they could be looked up. Prothero is a dictionaryist.

Dictionaryism, n. - the belief that the essence of a thing is contained in its dictionary entry. The boundaries of the thing, the limits on its growth, its most meaningful parts-are all renderable in words and are available under the appropriate heading. Dictionaryism holds that the Dictionary is What Is, that the words on the page are what matter.

Dictionaries are great. I use them all the time. But dictionaryism, as an ideology, takes the Good Idea of dictionaries a step further - too far. This is more complicated than a simple lapse into the Protestant bias we face every day in our American classrooms that a religion is reducible to articles of faith. Prothero is way past that debate, knowing full well that a religion is not just "a creed," sola fides- and he says so explicitly throughout his book (see, e.g., pages 21, 57, 198, 232). But the lingering force of religions as articulable — as basically just expansions from the nutshell editions of that fun "Guide to Savvy Converts” wheel that goes around with a 20 word summary of each tradition's beliefs, practices, advantages and disadvantages-is haunting the framework of this text. 
Prothero has opened up an important space for discussing meaningful differences between religions. The receptivity to difference that he proposes under the name "religious literacy" helps us understand a handful of problems. And, more importantly, it illustrates the complexity of religions, defeating the naïve impulse to manufacture myths about unknown religions and groups of people by filling those conceptual categories with rich, detailed, shifting content. This is where religious literacy as a pedagogy and practice - and this book, as a text of that practice-present invaluable resources.

At the same time, the boxes that he has built for these religions in the conceptual apparatus of his introduction are too clumsy. Religions are not just books that can be read and then put away in their separate shelves. And this is where the metaphor of religious literacy hits a wall. Understanding religions is not just about opening a book, but about knowing how to ask the right kind of questions. Where does this notion, this narrative, this normative claim come from? Who says something different but under the same name? Who else? What else? What's next? It's about knowing who to talk to, and how to put what they say in the context of religion as an organic, evolving system.

Many of the problems Prothero suggests can be better understood by attending to religious difference are, I believe, unintelligible to the very same perspective. The "rivalry" that Prothero points to between Islam and Christianity, for instance, has nothing to do with differences of doctrine, ritual, valuesnothing to do with differences of religion as such. Indeed, Islam and Christianity are sometimes at odds on the world stage not because they are too different, but because they are too much alike: both have a tendency towards orthodoxy based on books and dogma; both compete for membership in the same geographic arenas; and, most importantly, both have the lingering arrogant airs of empire, the memory - however fresh_of sitting on top of the world and the quiet, persistent conviction that that is where they belong.

The same can be said of the schism between Sunni and Shi'a, which Prothero returns to several times: there was no meaningful doctrinal difference that drove them apart. It was a question of power, influence, and the observance of pre-Islamic traditions. Listening to partisan Sunni-Shi'a debates now (which, wisely, many Sunnis and Shi' as have left aside) is like listening to teenage siblings argue over toothpaste. The divide between Catholic and Orthodox Christians is the same, ${ }^{1}$ and even, to an extent, is the divide between Catholic and Protestant. Were there differences in interpretation of Christian tradition that led to the great schism? Yes-but those differences were superimposed on a pre-existing terrain of political, economic, and military concerns - and, I would hasten to add, on the interpersonal dynamics of a few strong-willed individuals wielding enormous influence inside Catholic institutions. Nowadays, the theological differences between Catholics and Protestants are merely meaningless to the vast majority of practitioners who, as Prothero himself points out, rarely know what those differences are (82). No-one in Northern Ireland in the 1970s was upset that Protestants wanted them to stop going to confession. And the Ulster contempt for Catholics had only little to do with communion wine. It was a question of politics - ancient memories, access to the levers of power, national traumas suffered in vividly remembered wars. Histories, not dictionaries, are what we need here.

But doesn't this contradict our sense that people are telling us that religion is the reason that they fight? Why are there still conflicts in the world that are explicitly framed in terms of religion? Because, as Chris Hedges argues in his War is a Force that Gives Us Meaning (2003), there is a bodily imperative to manufacture differences, to define in-groups and out-groups, to go to war. Religion is a tool of this

\footnotetext{
1 The Great Schism was consolidated in 1204 by the Catholic victory over the Orthodox at Constantinople, as Prothero points out, not in the pages of theological debate, but on the battlefield. (75)
} 
imperative, not its origin. Religion is a technology that defines identities, not a book, not a system of beliefs. It is a tool of ideologies, nations, bodies, not an ideology itself.

A Prothero defender is going to respond that while this may be the case, there is a reason that there are, for instance, no Christian suicide bombers. This is true, but the reason, again, is not religion as such. The reason is history. Suicide bombing, as every scholar of religion and precious few others can tell you, appeared in force with the Hindu Tamil Tigers in their separatist war against the Buddhist Sinhalese majority in Sri Lanka. The roots of martyrdom go back much earlier, to the Maccabean revolt against Antiochus Epiphanes IV-where the Jewish tradition first began to develop a notion of afterlife rewards. The other most famous example of suicide attacks are the Buddhist-Shinto Japanese kamikaze pilots. So is the Islamic emphasis on the afterlife the reason that, in the last 20 years, about three quarters of the world's suicide attacks have been carried out by Muslims ${ }^{2}$ ? Maybe, but it's by no means obvious to me that that is the case. Any explanation for that would need to explain why this phenomenon is so new-and that explanation is going to come back around to history, to social, economic, military, and political pressures. It's going to need to account for non-religious bands of power reaching around the globe, combining and recombining to produce new forms that may take religion as their name, but are, in fact, historical.

In short, religion is a technology that makes certain political and personal configurations possible. But it is still subject to history, still buffeted by the regime of accidents that produces actual systems of meaning. This is the error of dictionaryism, to allow a textual description or even a textual prescription (a Quran, a Veda, a Tripitaka) to become determinative for a complex, multidimensional, historical artifact. Here, the dictionary is not just incomplete, but is probably going to give you the wrong answer. If Osama bin Laden had been born in a different, parallel timeline - in which his own pathologies and his own politics and his own encounter with history were identical, but he had a Bible in his hand instead of a Quran, he would be leading a pack of thugs taking their name from the Maccabees instead of calling themselves al-Qaeda.

This brings me to my second concern with dictionaryism. As a teenager I was given a beautiful, mid$20^{\text {th }}$-century, bound leather dictionary by my grandpa while I was visiting his house in Montreal. I happened to be going through a phase in which I was working hard to improve my vocabulary, which meant writing down words I didn't know from Borges and Camus and then looking them up, copying the definitions into my pocket notebook, and studying them on the bus. This project, I'm sorry to say, was significantly set back by my grandfather's gift. In the ensuing months, I copied down dozens of definitions that I later learned were archaic. This came to a head when I used the word "incontinently" in its mid-20 ${ }^{\text {th }}$-century-sanctioned meaning of "immediately" in an essay that I (thankfully) had my parents proofread before I submitted it as an assignment.

Dictionaries are not effective antennae for change. They do not register the subtle mutations that make up historical processes like religions. To set down the rules for a religion is very often to take a static snapshot of a tradition in a particular point in time. Dictionaryism systematizes this weakness, making it difficult for religions to be understood as historically embedded phenomena.

This error is most glaring in Prothero's work when he writes that he had "repeatedly [come] across respected scholars of Hinduism and Buddhism referring to 'sin' and 'salvation' as if these were Hindu and Buddhist concepts. But these are Christian ideas, so when writing about Hinduism and Buddhism, I will not use them.” (21) For Prothero, the vocabulary of a religious tradition is fixed and is the

2 As often against other Muslims as against non-Muslims. 
exclusive property of that tradition. If the dictionary says it goes, then it goes.

But Prothero's own content repudiates this error. The inner chapters of his text are filled with examples of religions borrowing from one another and incorporating core concepts through those exchanges: Hinduism is "forever absorbing” new influences (134) and contemporary Hindus often deny what others see as the erotic or sexual elements of their tradition, presumably, he writes because of the influence of British Victorianism (155); Buddhism had no creed at all until the American Henry Steel Olcott devised one, late in the $19^{\text {th }}$ century (172); the Yoruba comfortably hybridize Roman Catholicism and their own traditions (224); ancient Hebrew interaction with Greek religion and philosophy led to the notion of an afterlife in Judaism (266).

Once again, we see the inner chapters of this book bursting cheerfully out of the conceptual frame within which they have been unsuccessfully tacked. Religions change through interaction with one another. If D.T. Suzuki wants to explain Zen in terms of salvation, or if Vivekananda wants to explain his version of Hinduism in terms of sin, it is not our prerogative as scholars to point to the dictionary and refuse those avenues. Religions can knit together. They are not discrete slots waiting to be filled up with isolated content. Religions communicate, combine and recombine like genetic material. Religions can take on an affinity or similarity to other traditions that they come in contact with. Religions can change and mutate-either through the everpresent static noise of their environments or through their reproductive dances with other traditions-local customs, other traditions, people and groups.

One of the many methodological tactics Prothero uses that underpins both of these problems is his schema of religions as "problems." Prothero lays out this four-fold model in his introduction: each religion addresses a different "problem," a different sense that time is out of joint (1); lays out a particular solution (2) and techniques (3) for achieving that solution; and identifies an exemplar or exemplars who represent models (4) for the implementation of those techniques. (14-15)

This problem-defining model is exceptionally helpful, Prothero says, in the classroom, where it forms the backbone of his undergraduate instruction. It does seem like a useful and efficient way to get undergrads to start thinking about religions - encapsulating their central concerns and priorities in a single formula. But it is, I would argue, a distortive lens, one that makes religions intelligible to dictionaryism and that pinpoints differences, but fails to respect religions as living artifacts.

Prothero gives the initial examples of Buddhism and Christianity. His take on Buddhism here seems to me uncontroversial; indeed, his four-part model is a neat tracing of the Four Noble Truths that were preached at the outset of Buddhism — and Buddhism is, indeed, a preached religion-very helpful for defining it as problem-centered. But are all religions really so comfortable with this pattern?

Is there a problem in Hinduism? There are lots of problems, ${ }^{3}$ but there are also so many dimensions of Hinduism, so many distinct concerns corresponding to so many distinct layers of history, that to reduce the entire matrix of the religion to this four-part formula seems dangerous. ${ }^{4}$ Or what about Judaism?

$3 \quad$ As Prothero himself admits (144), so should these different philosophical and religious layers of Hinduism be different religions? Dictionaryism strikes again.

$4 \quad$ Incidentally, this emphasis on religions as problem-solving engines also leads Prothero into the handful of significant factual errors in his book. For instance, he writes that "this is how Hinduism began over 2,500 years ago-as an elite tradition of ascetics seeking to solve the problem of samsara through wisdom.” (138) I could find no scholars of Indian religion who accepted this view. (I'm sure there are some, but it is at best controversial—a fiction produced by a particular organizational lens of viewing religions as responses to problems.) It overlooks the pre-ascetic priestly/Vedic traditions that 
What's the problem at the heart of Judaism? The suffering of the Jews? A problem indeed, but that problem could only have been articulated after the formulation of a Jewish community. And this is where the dictionaryist formulation really falls down: religions are not generated by a wise man sitting down and articulating a problem and its solution (okay, maybe one or two... ${ }^{5}$ ). They are not only the summation (or a limited selection) of the teachings of a founder, but of a tradition of practices, notions, and narratives extending throughout the history (and prehistory) of a religion. Here, Prothero lapses into exactly the sort of myopic selectionism for which he (rightly) indicts Huston Smith and Karen Armstrong.

There's another aspect to my concern here, though, which is that the Big Problem schema is the only way to make Prothero's focus on difference, on the non-unity of the religions, intelligible. When we look at words, doctrines, ideas, the differences between religions become very visible, very quickly. There are different terminologies, different arrangements of concepts, different emphases (the afterlife in the Quran, psychology in the teachings of Buddha, ritual in the Vedas).

But another organizing principle for understanding religions might get us to a very different answeran answer that may or may not be satisfactory for the practitioners of the religions themselves, but just as often is. What about a look at religions not on the basis of problems, but of what they do for groups? What if we assessed religions in terms of its effects for producing identities, for generating community? Then we would have to admit that religions look much more alike, that through different paths they come to a similar outcome.

What if we organized religions according to experience? Prothero in chapter after chapter draws our attention to the "experiential" dimension of religions. What if we were evaluating affective modes like awe and dignity as the organizing principle of religions? Then, again, we would have to concede that the religions look much alike, with similar traits and objectives embedded in bodies. Prothero himself embraces this, at times, likening Hasidism to bhakti and then suggesting that, "[c]haracterized by fullthroated and fully embodied enthusiasm-Judaism as joy-their services recall the ecstatic prayer of Pentecostalism and the danced religion of the Yoruba.” (269)

What about ethics? Do religions produce compassionate subjects? What, for that matter, of religion as a set of what Foucault would call technologies of the self, disciplinary and self-disciplinary practices designed to transform us? What about all religions as a "way" in the Buddhist-Daoist-Shinto inflected sense of "Dao"/“Do," each religion as a path designed to accomplish self-transformation, like "The Way of Submission" or "The Way of Propriety" or "The Way of Devotion" or "The Way of Flourishing," et cetera? Here again, the commonality of the religions of the world is thrown into relief. Each of these organizing principles, what Michel Foucault in The Order of Things would call a "common locus," casts a different light on religions. Prothero, in defining religions according to problems, arbitrarily chooses one that highlights their differences - the different words and vocabulary

extend far back before the sannyasi-not to mention the network of local gods and the priestly offices and rituals that attached to them. This also leads to Prothero's assertion that "Moses and Abraham were not Jews" (262) — perhaps a less controversial assertion, but nonetheless one that tries to arbitrarily pinpoint the emergence of Judaism as a religion at the moment when it articulates a problem (during the Babylonian Exile). Somehow the ritual and sacrificial traditions preceding exile-which produced the Torah and at least part of the Deuteronomic history-are just a nameless preamble to "Judaism: The Way of Exile and Return," in Prothero's formulation.

$5 \quad$ In fact, it seems to me that this four-part model emerges so closely from the pattern of the Four Noble Truths that Buddhism must have been the template for it (just as the "all religions are one" model emerges out of a particular alliance/contact zone between Hinduism and Deism). It fits neatly in with a dictionaryist persuasion's emphasis on doctrine, on textually communicable knowledge. With the problem model, religions are essentially about ideas, a cosmology or picture of the universe as out of joint. 
that they present. He is not wrong, but his dictionary is, I believe, too narrow, a closed book.

\section{Conclusion}

I believe that there is an imperative in contemporary publishing to produce razor-sharp, body-blow arguments - books that take a strong, unambiguous stance and stick to it. I believe that scholarship in complex fields like religion is betrayed by this trend. I believe that taking a tough stand outsells taking a nuanced, practical outlook (look at Fox News for the former or Barack Obama's poll numbers for the latter), and that this is a tragedy. I believe that it is our job as academics - as people who have the time to digest the complex textures of information and circulate that information with as much of its original nuance intact- to resist this trend. A pithy title that grabs interest is fine. But intellectual stridency is not.

I could teach this book. I would ask students to analyze how the premises outlined in the Introduction were betrayed by the rich, exquisitely documented volumes of detail captured within. I would read the book against itself (to recapitulate one of the classic meanings of the term "deconstruction”), showing how its own system of meanings was undermined by its own premises. But I would never recommend this book to someone outside my field. I would not drop this book in someone's lap without the benefit of an ongoing conversation to reinscribe its meanings inside a more textured, nuanced, multiplicitous frame.

Let's also be careful, as scholars of religion, to accept a due measure of humility with respect to our subject matter. "Unfortunately," Prothero writes, "we live in a world where religion seems as likely to detonate a bomb as to defuse one.” (7) Well, sure, if you believe CNN_but the vast majority of people in the world are religious in ways that very rarely result in explosions. ${ }^{6}$ Religion matters and religious literacy is valuable. But we need to get better about not only pointing out where religion matters, but where it does not matter at all. Prothero says that there is no practical value for "diplomats," "entrepreneurs," or "soldiers" to be taught that religions are all the same, "or that Muslims, Christians, and Jews in Israel do not disagree fundamentally on matters of faith or practice.” (334) I have no wish to lump Prothero in with the Samuel Huntingtons of the world, from whom he actively distances himself, ${ }^{7}$ but I worry that an incautious overemphasis on difference makes it seem like these groups are in conflict because of their religions, when it is clear to me that religion is epiphenomenal at best to the real historical, political, and economic motives for violence-faces painted on the wall of the building where real decisions are made.

I remember seeing Karen Armstrong speak here in Syracuse and being left frustrated with the way she yoked the ethical imperatives of Jainism together with the ethical imperatives in Islam, Judaism, Buddhism, and the rest. The notion "be ethical" is too easy and empty of content. (Are you ethical to animals in the same way as you are to humans? Which animals?) There are different species of ethics, and to blithely blur those differences is, as Prothero says, deeply wrong.

But it is similarly wrong to think that religion is contained in a few pages, and I worry that the theme of acquiring religious literacy will produce inflexible regimes of knowledge that can't accommodate the hypercomplex, changing forms of religion-including the moments when religions knit together, fuse,

$6 \quad$ This is a variation of Prothero's own astute observation that there is a "persistent, unexplored bias in the study of religion toward the extraordinary and away from the ordinary” (107). I would ask Prothero to apply this same hermeneutic of suspicion to his own work, to ask if he is too much fixated on the points of fire and collision rather than the mundane majority.

Cf. pp. 12 and 335. 
hold hands or actively, intimately intertwine their branches. Religious literacy, I think, cuts both ways: we may acquire religious literacy, but religions, too, are literate. Religion reads us before we read it. It programs us, rewrites us, but it also takes what it wants from our DNA and incorporates those new images, concepts, gestures, words, YouTube vids, conversations, pamphlets, web sites, TV shows, memories, soundtracks, impressions, affects, and nervous habits into its own. A baseline of religious literacy - the kind of information presented with such appealing clarity by the inner chapters of this book - is precious to help us understand the wheeling forms of these religious matrixes as they unfold. But in the end, what dictionary can hold them? 